\title{
REGULARARTICLE \\ RESPONSE OF COWPEA (VIGNA UNGUICULATA L. WALP) VARIETIES TO PHOSPHORUS LEVELS IN SUDAN SAVANNA OF NIGERIA
}

\author{
MUSA M. ${ }^{1}$ BASHIR K. A. ${ }^{*}$, TADDA S. A. ${ }^{1}$
} ${ }^{1}$ Department of Crop Production and Protection, Faculty of Agriculture and Agricultural Technology, Federal University
Dutsin-ma, P. M. B 5001, Dutsin-Ma, Katsina State, Nigeria

${ }^{2}$ Department of Biological Sciences, Faculty of Science, Federal University Dutsin-ma, P. M. B 5001, Dutsin-ma, Katsina State, Nigeria

\begin{abstract}
The study was conducted to determine the response of cowpea varieties to phosphorus levels in the Sudan savannah of Nigeria. The treatments consisted of four cowpea varieties (UAM-09-1051-1, IT99K-573-2-1, IT99K-573-1-1, and TVX 3236) and phosphorus fertilizer (SSP) (o, 20, and $40 \mathrm{~kg} / \mathrm{ha}$ ) which were laid out in a Randomized Complete Block Design (RCBD). The result revealed that application of $40 \mathrm{~kg} / \mathrm{ha} \mathrm{P}_{2} \mathrm{O}_{5}$ statistically recorded the highest grain yield/ha at BUK. No significant phosphorus effect was recorded on grain yield/ha at Bagauda. The findings of the study also revealed that there was significant varietal effect on cowpea growth and yield at both study locations. Higher grain yield was recorded from variety IT99k-573-2-1 (1193.400 kg/ha), followed by variety TVX 3236 (950.900 kg/ha) and IT99k-573-1-1 (776.500 kg/ha) at BUK while no significant effect of variety was recorded at Bagauda. The result of the simple correlation analysis revealed significant negative and positive association between growth and yield parameters. Thus based on this findings, application of $40 \mathrm{~kg} / \mathrm{ha} \mathrm{P}_{2} \mathrm{O}_{5} \mathrm{can}$ be recommended for better cowpea growth and yield. Similarly, variety IT99k-573-2-1 can be recommended for both locations.
\end{abstract}

Keywords: Cowpea, Phosphorus, Varieties, Vigna unguiculata

\section{INTRODUCTION}

Cowpea (Vigna unguiculata L. walp) is a major leguminous food crop cultivated all over the world. It is a main nutritious crop and there are three cultivated species ( $V$. textilis, $V$. pubescens, and $V$. sinensis). This leguminous crop is being cultivated throughout the semiarid tropics [1]. This plant is suitable to these climates due to its ability to withstand in drought conditions. And this crop is a nitrogen fixing plant as well [1]. Cowpea can be consumed in all stages of its growth and can be used to prepare delicious dishes [2] and animal feed [3]. Due to its nitrogen fixing ability, it is having significant agronomic importance $[4,5]$. The cowpea is rich in many nutrients and minerals which are essential to human health [6].

Phosphorus (P) is important for plant growth but its availability is mostly limited. Root improvement, stalk and stem vigor, flower and seed formation, crop production, crop maturity and resistance to plant pests and diseases are the attributes associated with phosphorus availability. The limiting factors for cultivation and production loss of cowpea are many like abiotic factors and diseases [7]. The most important abiotic factor is the soil related constraints on cowpea production; low soil fertility is the most severe on more than half of the arable land in the tropics [8]. Infertile soils are usually acidic and present deficiencies of phosphorus (P) and Nitrogen (N) [9]; Potassium (K), toxicity of Aluminum (Al) and high p fixation capacity [10]. Phosphorus is major element required for plant growth [11] and its deficiencies due to environmental and cultivation factors limits plant growth and production [1214]. This research work was aimed to evaluate the response of cowpea varieties to phosphorus fertilizer levels.

\section{MATERIALS AND METHODS}

\section{Experimental site}

Field-trials were conducted during the 2015 rainy season at the Bayero University Kano Teaching and Research Farm ( $11^{\circ} 58^{\prime} \mathrm{N}, 8^{\circ} 25^{\prime} \mathrm{E}$ and $475 \mathrm{~m}$ above sea level) and National Institute of Horticulture (NIHORT) Bagauda (lat. $12{ }^{\circ} \mathrm{O} 8$ ' N, long. $8{ }^{\circ} 32^{\prime} \mathrm{E}, 500 \mathrm{~m}$ above sea level). Both sites are located in the Sudan savannah agro-ecological zone of Nigeria.

Received 02 November 2017; Accepted 31 December 2017

${ }^{*}$ Corresponding Author

Bashir K. A.

Department of Biological Sciences, Faculty of Science, Federal University Dutsin-ma, P. M. B 5001, Dutsin-ma, Katsina State, Nigeria

Email: abdoolkut12@gmail.com

( This article is open access and licensed under the terms of the Creative Commons Attribution License (http://creativecommons.org/licenses/by/4.o/) which permits unrestricted, use, distribution and reproduction in any medium, or format for any purpose, even commercially provided the work is properly cited. Attribution - You must give appropriate credit, provide a link to the license, and indicate if changes were made. 


\section{Treatments and experimental design}

The experiment consisted of twelve (12) treatments in three replications. The treatments consisted of four cowpea varieties (UAMo9-1051-1, IT99K-573-2-1, IT99K-573-1-1, and TVX 3236), and three levels of phosphorus fertilizer (SSP) (o, 20 , and $40 \mathrm{~kg} / \mathrm{ha}$ ) which were laid out in Randomized Complete Block Design (RCBD). The total plot size was $13.5 \mathrm{~m}^{2}$ (gross plot) and $3.375 \mathrm{~m}^{2}$ (net plots) respectively.

\section{Varietal description}

TVX 3236 is a wrinkle, rhomboid, cream/brown seeded variety with small seed size and brown helium it is high yielding semi-erect and is susceptible to striga infestation $1000-1200 \mathrm{~kg} / \mathrm{ha}$. IT99K-573-2-1 is a medium maturing, semi erect, and semi determinate crop. The seed is white with brown helium the seeds are rough and can yield about 1997.0 kg/ha. IT99K-573-1-1 is a medium maturing, semi erect, and semi determinate crop. The seed is white with black helium the seeds are rough and can yield about 2192.5 kg/ha. UAM 09-1051-1 is a medium maturing crop with pearl brown seeds, the seeds are rough with a brown helium it is susceptible to striga infestation. It has an estimated yield of $1050 \mathrm{~kg} / \mathrm{ha}$.

\section{Cultural practices}

The land was harrowed, ploughed and ridged at $75 \mathrm{~cm}$ apart using tractor after which the plots were demarcated. A space of $1 \mathrm{~m}$ between the plots and $2 \mathrm{~m}$ between replicates was used as borders. The seeds were sown immediately at three seeds per hole at an intra-row spacing of $0.20 \mathrm{~m}$. The seedlings were thinned to two plants per stand at two weeks after sowing. Two manual hoe weddings were done at 3 and $6 \mathrm{w}$ after sowing using a narrow bladed hoe. Phosphorus fertilizer was applied basally on treatment basis in form of Single Super Phosphate (SSP) using drill method before sowing. Insect pest observed on the field were treated accordingly. This was carried out from pre-flowering to flowering and pod formation stages at weekly interval using karate 5 EC and Judo (lambda cyhalothrin 2.5\% EC) in 15 $\mathrm{ml}$ of water using knapsack sprayer. Pods were harvested at maturity when the leaves turned from pale green to yellow and fall off the stem and also the pods turned yellow at weekly interval. Pods of the five tagged plants from the sampling rows were weighed to determine pod weight, while the entire net plots $(0.75 \mathrm{~m} \times 4.5 \mathrm{~m})$ were subsequently harvested, collected into a viva poly bag, labeled then sundried to facilitate threshing.

\section{Data collection}

Data were collected from the net plots leaving the gross plots to serve as borders. Data collected were based on growth and yield parameters. The growth and yield parameters include: Emergence count, Plant height (cm), Number of branches/plant, Number of leaves/plant, Leaf area index, Leaf chlorophyll content, Average number of pods/plant, Average pod weight/plant (g), Number of seed/pod, Hundred seed weight (g) and Grain yield (kg/ha).

\section{Data analysis}

The data generated were subjected to Analysis of Variance (ANOVA) procedure for Randomise Complete Block Design (RCBD). F-test was used to test for the level of significance, mean separation was carried out using Duncan New Multiple Range Test (DNMRT) at $\mathrm{P} \leq 0.05$. Simple correlation analysis of the growth and yield component was carried out to determine the relationship existing between them.

\section{RESULTS}

\section{Emergence count}

The effect of phosphorus and variety on emergence count of cowpea is presented in table 1 . There was no significant effect of phosphorus on the emergence count of cowpea at both locations. There was no significant influence of variety on the emergence count of cowpea at both locations.

\section{Plant height}

Plant heights of cowpea as influenced by phosphorus and variety during the 2015 wet season are presented in table 2. The effect of phosphorus on plant height of cowpea was only significant at $3 \mathrm{w}$ after sowing (WAS) in Bagauda where application of 20 and $40 \mathrm{~kg} \mathrm{P}_{2} \mathrm{O}_{5} /$ ha resulted in taller plants compared to plants not treated with phosphorus which significantly produced shorter plants.

The effect of variety on plant height was only significant at 9 WAS at BUK and at all sampling periods at Bagauda. At 9 WAS in BUK, variety IT99K-573-1-1 significantly recorded taller plants which were comparable to variety IT99K-573-2-1 and UAM-09-1051-1. Variety TVX 3236 produced the shortest plants. Also at 3 and 6 WAS at Bagauda, variety IT99K-573-1-1 which were statistically comparable to variety IT99K-573-2-1, while the shortest plants were produced by variety TVX 3236 . However at 9 WAS in Bagauda, varieties IT99K-573-1-1 and IT99K-5732-1 produced significantly taller plants than the other varieties which produced the shortest plants.

Table 1: Emergence count of cowpea as affected by phosphorus and variety during the 2015 wet season

\begin{tabular}{lll}
\hline Treatments & Buk & Bagauda \\
\hline PHOSPHORUS & Emergence count & Emergence count \\
o kg/ha & & \\
20 kg/ha & 58.625 & 59.083 \\
$40 \mathrm{~kg} / \mathrm{ha}$ & 53.870 & 57.208 \\
SE & 47.792 & 57.375 \\
VARIETY & 4.531 & 1.534 \\
IT99K-573-1-1 & & \\
IT99K-573-2-1 & 43.667 & 58.333 \\
UAM-09-1051-1 & 52.882 & 58.778 \\
TVX 3236 & 60.515 & 55.974 \\
SE \pm & 60.135 & 58.647 \\
\hline
\end{tabular}

Means followed by the same letter (s) in a in a column are not significantly different at $5 \%$ level of probability using Duncan Multiple Range Test (DNMRT). P: Phosphorus, V: variety, 
Table 2: Plant height (cm) of cowpea as affected by phosphorus and variety during the 2015 wet season

\begin{tabular}{|c|c|c|c|c|c|c|}
\hline \multirow[t]{2}{*}{ Treatments } & \multicolumn{3}{|l|}{ BUK } & \multicolumn{3}{|l|}{ Bagauda } \\
\hline & 3WAS & 6WAS & 9WAS & 3WAS & 6WAS & 9WAS \\
\hline PHOSPHORUS & & & & & & \\
\hline o kg/ha & 32.629 & 85.801 & 135.160 & $28.700^{b}$ & 61.348 & 78.323 \\
\hline $20 \mathrm{~kg} / \mathrm{ha}$ & 29.622 & 86.09 & 141.900 & $30.642^{\mathrm{a}}$ & 67.529 & 84.882 \\
\hline $40 \mathrm{~kg} / \mathrm{ha}$ & 32.629 & 92.626 & 126.410 & $30.258^{a}$ & 66.715 & 91.341 \\
\hline $\mathrm{SE}_{ \pm}$ & 1.974 & 5.621 & $9 \cdot 365$ & 0.497 & 3.684 & $5 \cdot 513$ \\
\hline VARIETY & & & & & & \\
\hline IT99K-573-1-1 & 35.817 & 100.719 & $156.19^{\mathrm{a}}$ & $31.65^{6}$ & $79.942^{\mathrm{a}}$ & $100.25^{\mathrm{a}}$ \\
\hline IT99K-573-2-1 & 29.529 & 88.406 & $133.330^{\mathrm{ab}}$ & $31.011^{\mathrm{ab}}$ & $68.149^{\mathrm{ab}}$ & $98.403^{\mathrm{a}}$ \\
\hline UAM-09-1051-1 & 29.874 & 84.108 & $131.140^{\mathrm{ab}}$ & $29.379^{b}$ & $62.295^{\mathrm{b}}$ & $70.904^{b}$ \\
\hline TVX 3236 & 30.994 & 79.325 & $115.980^{b}$ & $27.306^{c}$ & $49.755^{c}$ & $69.774^{\mathrm{b}}$ \\
\hline $\mathrm{SE} \pm$ & 2.286 & 6.501 & 10.843 & 0.575 & 4.266 & 6.383 \\
\hline
\end{tabular}

Means followed by the same letter (s) in a in a column are not significantly different at $5 \%$ level of probability using Duncan Multiple Range Test (DNMRT). NS: P: Phosphorus, V: variety.

\section{Number leaves}

Number of leaves per cowpea plant as affected by phosphorus, and variety during the 2015 wet seasons are presented in table 3 . The effect of phosphorus on number of leaves of cowpea was only significant at 3 WAS in BUK where application of $20 \mathrm{~kg} \mathrm{P}_{2} \mathrm{O}_{5} /$ ha resulted in more number of leaves per plant which were statistically comparable to plant that received $40 \mathrm{~kg} \mathrm{P}_{2} \mathrm{O}_{5} / \mathrm{ha}$, while plants not treated with phosphorus recorded the least number of leaves per plant. The effect of variety on number of leaves per plant was only Significant at 3 and 6 WAS at BUK and at all sampling period at Bagauda.

At 3 WAS in BUK variety TVX 3236 significantly recorded more number of leaves which was comparable to variety IT99K-573-1-1, the least number of leaves per plant were recorded by variety IT99K-573-2-1, also at 6 WAS variety TVX 3236 produced the highest number of leaves per plant which was statistically comparable to variety UAMo91051-1. Varieties IT99K-573-1-1 and IT99K-573-2-1 produced the least number of leaves per plant. At 3 WAS in Bagauda, variety IT99K-573-2-1 recorded the highest number of leaves which were statistically comparable to other varieties except variety UAMo9-1051-1which produced the least number of leaves. The least number of leaves was recorded from variety UAMo9-1051-1 and IT99K-573-2-1 respectively. At 6 WAS variety TVX 3236 produced statistically more number of leaves than variety IT99K-573-2-1 but was statistically comparable to the other varieties. However at 9 WAS in Bagauda, variety TVX 3236 produced more number of leaves which were statistically at par with variety IT99K-573-2-1 while variety UAM09-1051-1 recorded least number of leaves.

\section{Number of branches}

The influence of phosphorus and variety on average number of branches of cowpea is shown in table 4. There was no significant difference on the effect of Phosphorus on number of branches at both locations and sampling periods. The effect of variety on number of branches was significant at both locations and sampling periods. At 3 WAS in BUK variety TVX 3236 significantly recorded the highest number of branches which were comparable to variety IT99K-573-1-1 and UAMo9-1051-1, variety IT99K573-2-1 recorded the lowest number of branches. However, at 6 and 9 WAS variety TVX 3236 significantly recorded the highest number of branches which were comparable to variety IT99K-573-2-1 and UAMO9-1051-1. Variety IT99K573-1-1 recorded the lowest number of branches respectively. Also at all sampling period in Bagauda, variety TVX 3236 significantly and consistently recorded the highest number of branches than the other varieties but was comparable to IT99K-573-2-1 at 3 WAS, and UAMo9-1051-1 at 6 and 9 WAS.

Table 3: Cowpea number of leaves as affected by phosphorus and variety during the 2015 wet season

\begin{tabular}{|c|c|c|c|c|c|c|}
\hline \multirow[t]{2}{*}{ Treatments } & \multirow{2}{*}{$\begin{array}{l}\text { BUK } \\
\text { 3WAS }\end{array}$} & \multicolumn{5}{|c|}{ Bagauda } \\
\hline & & 6WAS & 9WAS & 3WAS & 6WAS & 9WAS \\
\hline \multicolumn{7}{|l|}{ PHOSPHORUS } \\
\hline $\mathrm{o} \mathrm{kg} / \mathrm{ha}$ & $18.142^{b}$ & 121.428 & 130.250 & 16.267 & 98.525 & $95 \cdot 33$ \\
\hline $20 \mathrm{~kg} / \mathrm{ha}$ & $20.765^{\mathrm{a}}$ & 118.997 & 121.040 & 18.600 & 96.721 & 101.58 \\
\hline $40 \mathrm{~kg} / \mathrm{ha}$ & $19.333^{\mathrm{ab}}$ & 117.903 & 126.400 & 17.025 & 98.525 & 108.63 \\
\hline $\mathrm{SE} \pm$ & 0.714 & 5.102 & 8.077 & 0.803 & 6.913 & 7.157 \\
\hline \multicolumn{7}{|l|}{ VARIETY } \\
\hline IT99K-573-1-1 & $20.478^{\mathrm{ab}}$ & $112.340^{\mathrm{b}}$ & $114 \cdot 390$ & $16.667^{\mathrm{ab}}$ & $95.20^{\mathrm{ab}}$ & $100.00^{b c}$ \\
\hline IT99K-573-2-1 & $16.624^{c}$ & $110.616^{b}$ & 122.240 & $8.778^{\mathrm{a}}$ & $80.29^{b}$ & $104.33^{\mathrm{ab}}$ \\
\hline UAM-09-1051-1 & $18.295^{\mathrm{bc}}$ & $121.059^{\mathrm{ab}}$ & 136.470 & $15.768^{b}$ & $95 \cdot 39^{\mathrm{ab}}$ & $79.16^{c}$ \\
\hline TVX 3236 & $22.247^{\mathrm{a}}$ & $134.010^{\mathrm{a}}$ & 130.210 & $18.106^{\mathrm{ab}}$ & $114.4^{\mathrm{a}}$ & $126.53^{\mathrm{a}}$ \\
\hline $\mathrm{SE} \pm$ & 0.827 & 5.907 & 9.352 & 0.929 & 8.004 & 8.285 \\
\hline
\end{tabular}

Means followed by the same letter (s) in a in a column are not significantly different at $5 \%$ level of probability using Duncan Multiple Range Test (DNMRT). P: Phosphorus, V: variety. 
Table 4: Number of cowpea branches as affected by phosphorus and variety during the 2015 wet season

\begin{tabular}{|c|c|c|c|c|c|c|}
\hline Treatments & Buk & & & Bagaud & & \\
\hline & 3WAS & 6WAS & 9WAS & 3WAS & 6WAS & 9WAS \\
\hline \multicolumn{7}{|l|}{ PHOSPHORUS } \\
\hline o kg/ha & 5.988 & 14.287 & 14.680 & 5.283 & 10.924 & 14.652 \\
\hline $20 \mathrm{~kg} / \mathrm{ha}$ & 6.661 & 14.489 & 14.017 & 5.100 & 11.669 & 14.860 \\
\hline $40 \mathrm{~kg} / \mathrm{ha}$ & 6.029 & 14.331 & 17.477 & 5.283 & 11.829 & 14.468 \\
\hline $\mathrm{SE} \pm$ & 0.286 & 0.616 & 0.472 & 0.137 & 0.387 & 0.436 \\
\hline \multicolumn{7}{|l|}{ VARIETY } \\
\hline IT99K-573-1-1 & $6.050^{\mathrm{ab}}$ & $12.404^{\mathrm{b}}$ & $13.282^{\mathrm{b}}$ & $5.033^{b c}$ & $10.646^{b}$ & $14.166^{\mathrm{ab}}$ \\
\hline IT99K-573-2-1 & $5 \cdot 518^{\mathrm{b}}$ & $13.546^{\mathrm{ab}}$ & $14.979^{\mathrm{ab}}$ & $5.189^{\mathrm{ab}}$ & $11.192^{\mathrm{b}}$ & $13.944^{\mathrm{b}}$ \\
\hline UAM-09-1051-1 & $6.516^{\mathrm{ab}}$ & $15.119^{\mathrm{ab}}$ & $15.105^{\mathrm{ab}}$ & $4.716^{c}$ & $11.497^{\mathrm{ab}}$ & $14.963^{\mathrm{ab}}$ \\
\hline TVX 3236 & $6.771^{\mathrm{a}}$ & $16.426^{\mathrm{a}}$ & $18.463^{\mathrm{a}}$ & $5.565^{\mathrm{a}}$ & $12.623^{\mathrm{a}}$ & $15.628^{a}$ \\
\hline $\mathrm{SE} \pm$ & 0.330 & 0.713 & 0.547 & 0.158 & 0.449 & 0.504 \\
\hline
\end{tabular}

Means followed by the same letter (s) in a in a column are not significantly different at $5 \%$ level of probability using Duncan Multiple Range Test (DNMRT). P: Phosphorus, V: variety.

\section{Chlorophyll content}

The influence of phosphorus and variety on the chlorophyll content of cowpea is shown in table 5. There was no significant difference on the effect of Phosphorus on the chlorophyll content of cowpea at both locations and sampling periods. The effect of variety on chlorophyll content of cowpea was significant at both locations and sampling periods.

At 4 WAS in BUK variety IT99K-573-2-1 and UAM-091051-1significantly produced higher chlorophyll content while variety IT99K-573-1-1 produced the lowest chlorophyll content. At 8 WAS, variety UAM-09-1051-1 significantly produced higher chlorophyll content, variety IT99K-573-1-1 and TVX 3236 displayed lower chlorophyll content.

However at Bagauda in both sampling periods, variety IT99K-573-2-1 and UAM-09-1051-1 significantly recorded the highest chlorophyll content than IT99K-573-1-1 and TVX 3236 which produced the least chlorophyll content.

\section{Leaf area index}

The effect of Phosphorus and variety as well as their interactions on leaf area index of cowpea is presented in table 6. The effect of Phosphorus on leaf area index was only significant at 3 and 9 WAS at Bagauda, where the application of $40 \mathrm{kgP}_{2} \mathrm{O}_{5}$-ha recorded higher leaf area index but was comparable to leaf area index in plots that received $20 \mathrm{kgP}_{2} \mathrm{O}_{5}{ }^{\text {-ha }}$ and the control at $9 \mathrm{WAS}$.

The effect of variety on leaf area index of cowpea was only significant at 9 WAS at BUK and at all sampling periods at Bagauda. At 9 WAS in BUK, variety IT99K-573-1-1 and IT99K-573-2-1 recorded the highest leaf area index which were statistically similar with variety UAMo9-1051-1. However, at 3 WAS in Bagauda, variety UAMo9-1051-1 and IT99K-573-1-1 produced the highest leaf area index which was statistically similar to variety IT99K-573-2-1.

At 6 WAS, variety UAMo9-1051-1 produced higher leaf area index that was comparable to variety IT99K-573-1-1 while at 9 WAS sampling period, variety IT99K-573-1-1 and UAMO9-1051-1 significantly produced higher leaf area index and were statistically the same. Lower leaf area index was obtained from variety TVX 3236.

Table 5: Chlorophyll content of cowpea as affected by phosphorus and variety during the 2015 wet season

\begin{tabular}{|c|c|c|c|c|}
\hline \multirow[t]{2}{*}{ Treatments } & \multirow{2}{*}{$\begin{array}{l}\text { Buk } \\
\text { 4WAS }\end{array}$} & \multicolumn{3}{|c|}{ Bagauda } \\
\hline & & 8WAS & 4WAS & 8WAS \\
\hline \multicolumn{5}{|l|}{ PHOSPHORUS } \\
\hline o kg/ha & 62.829 & 91.972 & 59.783 & 73.560 \\
\hline $20 \mathrm{~kg} / \mathrm{ha}$ & 63.987 & 93.644 & 58.256 & 67.860 \\
\hline $40 \mathrm{~kg} / \mathrm{ha}$ & 62.681 & 89.515 & 53.362 & 86.800 \\
\hline $\mathrm{SE} \pm$ & 2.621 & 2.399 & 2.648 & $3 \cdot 31$ \\
\hline \multicolumn{5}{|l|}{ VARIETY } \\
\hline IT99K-573-1-1 & $46.533^{c}$ & $81.116^{c}$ & $45 \cdot 45^{2^{b}}$ & $62.183^{b}$ \\
\hline IT99K-573-2-1 & $71.376^{a}$ & $100.298^{b}$ & $66.616^{a}$ & $78.231^{\mathrm{a}}$ \\
\hline UAM-09-1051-1 & $77.868^{a}$ & $112.285^{\mathrm{a}}$ & $65.266^{\mathrm{a}}$ & $86.763^{\mathrm{a}}$ \\
\hline TVX 3236 & $56.085^{b}$ & $71.231^{\mathrm{c}}$ & $50.373^{b}$ & $55 \cdot 371^{\mathrm{b}}$ \\
\hline $\mathrm{SE} \pm$ & 3.035 & 2.777 & 3.066 & 3.832 \\
\hline
\end{tabular}

Means followed by the same letter (s) in a in a column are not significantly different at $5 \%$ level of probability using Duncan Multiple Range Test (DNMRT). P: Phosphorus, V: variety. 
Table 6: Leaf area index as affected by phosphorus and variety during the 2015 wet season

\begin{tabular}{|c|c|c|c|c|c|c|}
\hline \multirow{2}{*}{ Treatments } & \multirow{2}{*}{$\begin{array}{l}\text { BUK } \\
\text { 3WAS }\end{array}$} & \multicolumn{5}{|c|}{ Bagauda } \\
\hline & & 6WAS & 9WAS & 3WAS & 6WAS & 9WAS \\
\hline \multicolumn{7}{|l|}{ PHOSPHORUS } \\
\hline o kg/ha & 86.284 & 89.190 & 97.746 & $36.908^{b}$ & 43.426 & $40.671^{\mathrm{ab}}$ \\
\hline $20 \mathrm{~kg} / \mathrm{ha}$ & 86.570 & 88.410 & 86.096 & $36.329^{\mathrm{ab}}$ & 43.988 & $38.785^{b}$ \\
\hline $40 \mathrm{~kg} / \mathrm{ha}$ & 83.230 & 100.670 & 83.503 & $42.820^{\mathrm{a}}$ & 45.403 & $45.176^{a}$ \\
\hline $\mathrm{SE} \pm$ & 16.400 & 5.247 & $5 \cdot 366$ & 1.738 & 2.457 & 2.027 \\
\hline \multicolumn{7}{|l|}{ VARIETY } \\
\hline IT99K-573-1-1 & $117 \cdot 310$ & 85.42 & $92.654^{\mathrm{a}}$ & $42.305^{\mathrm{a}}$ & $44.011^{\mathrm{ab}}$ & $44.771^{\mathrm{a}}$ \\
\hline IT99K-573-2-1 & 79.14 & 92.32 & $100.218^{a}$ & $38.936^{\mathrm{ab}}$ & $41.344^{b}$ & $41.691^{\mathrm{ab}}$ \\
\hline UAM-09-1051-1 & 87.25 & 85.66 & $89.097^{\mathrm{ab}}$ & $42.067^{a}$ & $50.018^{a}$ & $44.168^{\mathrm{a}}$ \\
\hline TVX 3236 & 85.43 & 109.15 & $74.461^{\mathrm{b}}$ & $35.044^{\mathrm{b}}$ & $41.226^{b}$ & $35.039^{\mathrm{b}}$ \\
\hline $\mathrm{SE}_{ \pm}$ & 18.993 & 6.007 & 6.205 & 2.012 & 2.845 & 2.346 \\
\hline
\end{tabular}

Means followed by the same letter (s) in a in a column are not significantly different at $5 \%$ level of probability using Duncan Multiple Range Test (DNMRT). P: Phosphorus, V: variety.

\section{Number of pods per plant}

The effect of Phosphorus and variety on number of pods per plant of cowpea is presented in table 7. At both location and sampling period the effect of phosphorus on number of pods per plant of cowpea were not significant. The effect of variety on number of pods per plants was only significant at Bagauda. Variety UAMo9-1051-1 and TVX 3236 produced more number of pods and were statistically similar while variety IT99K-573-1-1 produced the least number of pods per plant.

\section{Number of seeds per pod}

The number of seeds per plant of cowpea as affected by Phosphorus during the 2015 wet season is presented in table 7. There was no significant influence of phosphorus and variety on the number of seeds per pod of cowpea at both locations and sampling periods.

\section{Pod weight per plant}

The influence of Phosphorus and variety on average Pod weight per plant of cowpea is presented in table 7 . There was no significant influence of phosphorus on the number of seeds per pod of cowpea at both locations. The effect of variety on average pod weight per plant of cowpea was only significant at Bagauda. Varieties IT99K-573-1-1, IT99K-573-2-1 and UAM09-1051-1 produced more pod weights and were statistically the same, while variety TVX 3236 produced the lowest pod weight per plant.

\section{0o seed weight (g)}

The influence of Phosphorus and variety on 100 seed weight of cowpea is shown in table 8. The effect of phosphorus on 100 seed weight of cowpea at both locations was not significant. The effect of variety on 100 seed weights of cowpea was only significant at BUK. Variety IT99K-573-2-1 produced the highest 100 seed weight which was comparable to the one produced by variety IT99K-573-1-1. Variety UAMo9-1051-1 and TVX 3236 gave low 100 seed weight.

\section{Grain yield kg/ha}

The influence of Phosphorus and variety on yield of cowpea in 2015 wet season at both locations is presented in table 8. Effect of phosphorus on grain yield $\mathrm{kg} / \mathrm{ha}$ of cowpea was only significant at BUK where the application of $40 \mathrm{~kg} \mathrm{P}_{2} \mathrm{O}_{5}$-ha resulted to higher yield compared to plant not treated with phosphorus but was statistically comparable plots that received $20 \mathrm{~kg} \mathrm{P}_{2} \mathrm{O}_{5}$-ha. The effect of variety on grain yield of cowpea was only significant at BUK. Where variety IT99K-573-2-1 gave the highest grain yield, variety IT99K-573-1-1 and UAMo9-1051-1 gave the lowest grain yield.

Table 7: Number of pods/plant, number of seeds per pod and pod weight/plant as affected by phosphorus and variety during the 2015 wet season

\begin{tabular}{lllllll}
\hline Treatments & Buk & & & Bagauda & \\
\hline & $\begin{array}{l}\text { No of } \\
\text { pods/plant }\end{array}$ & $\begin{array}{l}\text { No of } \\
\text { seeds/pod }\end{array}$ & $\begin{array}{l}\text { Pod } \\
\text { weight/plant }\end{array}$ & $\begin{array}{l}\text { No of } \\
\text { pods/plant }\end{array}$ & $\begin{array}{l}\text { No of } \\
\text { seeds/pod }\end{array}$ & $\begin{array}{l}\text { Pod } \\
\text { weight/plant }\end{array}$ \\
\hline PHOSPHORUS & & & & & & \\
o kg/ha & 12.139 & 12.334 & 2.131 & 14.430 & 11.861 & 2.377 \\
20 kg/ha & 12.898 & 11.217 & 1.959 & 14.522 & 11.958 & 2.199 \\
40 kg/ha & 12.847 & 11.812 & 2.037 & 16.014 & 11.833 & 2.299 \\
SE \pm & 0.169 & 0.452 & 0.665 & 0.316 & 0.689 & 0.097 \\
VARIETY & & & & & & \\
IT99K-573-1-1 & 11.388 & 11.222 & $2.166^{\mathrm{ab}}$ & $14.020^{\mathrm{ab}}$ & 11.388 & $2.286^{\mathrm{a}}$ \\
IT99K-573-2-1 & 13.608 & 12.177 & $2.327^{\mathrm{a}}$ & $13.528^{\mathrm{b}}$ & 11.889 & $2.387^{\mathrm{a}}$ \\
UAM-09-1051- & 12.999 & 11.825 & $1.983^{\mathrm{ab}}$ & $16.211^{\mathrm{a}}$ & 12.001 & $2.52^{\mathrm{a}}$ \\
1 & & & & & & \\
TVX 3236 & 12.530 & 12.000 & $1.698^{\mathrm{b}}$ & $16.195^{\mathrm{a}}$ & 12.272 & $1.905^{\mathrm{b}}$ \\
SE \pm & 0.769 & 0.522 & 0.196 & 0.1124 & 0.797 & 0.366 \\
\hline
\end{tabular}

Means followed by the same letter (s) in a in a column are not significantly different at $5 \%$ level of probability using Duncan Multiple Range Test (DNMRT). P: Phosphorus, V: variety. 
Table 8: 100 seed weight and yield in $\mathrm{kg} / \mathrm{ha}$ of cowpea as affected by phosphorus and variety during the 2015 wet season

\begin{tabular}{|c|c|c|c|c|}
\hline Treatments & Buk & & Bagauda & \\
\hline & 10o seed weight(g) & Yield kg/ha & 100 seed weight(g) & Yield kg/ha \\
\hline \multicolumn{5}{|l|}{ PHOSPHORUS } \\
\hline $\mathrm{o} \mathrm{kg} / \mathrm{ha}$ & 19.100 & $735 \cdot 500^{b}$ & 18.6292 & 635.630 \\
\hline $20 \mathrm{~kg} / \mathrm{ha}$ & 22.853 & $875.900^{\mathrm{ab}}$ & 18.5583 & 654.690 \\
\hline $40 \mathrm{~kg} / \mathrm{ha}$ & 22.601 & $1110.100^{\mathrm{a}}$ & 18.3625 & 644.810 \\
\hline $\mathrm{SE} \pm$ & 1.879 & 85.160 & 0.498 & 105.563 \\
\hline \multicolumn{5}{|l|}{ VARIETY } \\
\hline IT99K-573-1-1 & $21.302^{\mathrm{ab}}$ & $776.500^{b}$ & 17.989 & 607.500 \\
\hline IT99K-573-2-1 & $26.882^{\mathrm{a}}$ & $1193.400^{\mathrm{a}}$ & 18.478 & 637.300 \\
\hline UAM-09-1051-1 & $19.605^{\mathrm{b}}$ & $729.000^{b}$ & 18.800 & 772.400 \\
\hline TVX 3236 & $18.183^{b}$ & $950.900^{\mathrm{ab}}$ & 18.800 & 550.600 \\
\hline $\mathrm{SE}_{ \pm}$ & 2.175 & 98.597 & 1.1608 & 64.692 \\
\hline
\end{tabular}

Means followed by the same letter (s) in a in a column are not significantly different at $5 \%$ level of probability using Duncan Multiple Range Test (DNMRT). P: Phosphorus, V: variety.

\section{DISCUSSION}

Treating cowpea with $40 \mathrm{~kg} / \mathrm{ha} \mathrm{P}_{2} \mathrm{O}_{5}$ gave a significant increase in plant height, number of leaves, and leaf area index. This could be attributed to the positive response of cowpea to phosphorus as a vital compound of DNA. Increase in plant height leads to proportionate in number of leaves and branches with more chlorophyll content embedded which is critical in photosynthesis, dry matter accumulation and assimilates translocation from the source to the sink. This result agrees with the findings of [15] whom reported that Phosphorus fertilizer significantly enhanced growth and yield characters of the cowpea varieties used; plant height, leaf area, number of leaves and number of branches in all the weeks of measurement were significantly improved. This result is in conformity to the results observed earlier [16].

The non-significant response of some of the growth parameters recorded could be due to the lower soil $\mathrm{pH}$ which could have affected the supplied $\mathrm{P}$ and resulted to slow release. Phosphorus in soil is generally abundant, but at $\mathrm{pH}<5.5$ it reacts readily with Aluminum and calcium to form insoluble compounds in which the reaction results in very low phosphorus availability and efficiency of phosphorus fertilizer use by plant.

The significant effect of phosphorus on grain yield in this study indicated that $40 \mathrm{~kg} / \mathrm{haP}_{2} \mathrm{O}_{5}$ gave better result. This result is in conformity with the findings of other researchers; [16-19] who also discovered significant increase in yield of cowpea in response to phosphorus application.

Various previous studies reported the importance of $\mathrm{P}$ level and its supply on the production of crops [20-22]. However, some reports stated that the addition of phosphorus didn't affect the cow pea growth [23].

\section{Effect of variety on yield and growth of cowpea}

Variety IT99K-573-2-1 produced taller plants compared to other varieties used in both locations. While throughout the sampling period at Bagauda, variety IT99K-573-1-1 produced taller plants.

Significant effect was also observed on number of leaves and number of branches, variety TVX 3236 gave more number of leaves and branches at both the study locations.
Significant chlorophyll content was observed in variety IT99K-573-2-1 and UAM09-1051-1. Similarly, significant effect was also observed where variety IT99K-573-2-1 and IT99K-573-1-1 gave higher LAI, while variety TVX 3236 produced more number of root nodules at Bagauda. This can be attributed to response of photosynthetic apparatus to increased demand for assimilates due to rapid seed growth and development.

Varietal influence on number of pods, number of seed per pod, and pod weight per plant was observed during this study. Significant pod weight was observed in variety IT99K-573-2-1 (BUK), higher number of pods per plant was found in variety UAMo9-1051-1 and TVX 3236, and variety IT99K-573-1-1, IT99K-573-2-1 and UAM09-1051-1 gave higher pod weight per plant in Bagauda. Higher seed yield ${ }^{\text {-ha }}$ was obtained from variety IT99K-573-2-1 followed by variety IT99K-573-1-1. This result is in line with the findings of [15] who reported that High yield values were observed in variety three; IT99K-573-2-1, followed by variety two; IT99K-573-1-1 and variety one; IT97K-499-35. This is because, highest value in most of the yield characters measured was observed in variety three: IT99K573-2-1 at phosphorus fertilizer rate of $40 \mathrm{kgha-1}$, this contradicts the previous findings [13] in which highest yield recorded at $30 \mathrm{~kg}$ ha-1 and [19] who reported highest yield at 60 kgha-1 and suggested that may be the optimum as further application of phosphorus may or may not increase yield of cowpea.

\section{CONCLUSION}

Amongst the improved varieties used for this research, variety IT99k-573-2-1 gave a significant higher yield. The application of $40 \mathrm{~kg} / \mathrm{ha}$ phosphorus fertilizer produced a significant higher yield. This could be the best fertilizer level for cowpea growth and development, as well as yield of cowpea in the Sudan savanna Agro-ecological zone as observed in this study. Thus, phosphorus and improved variety can bring about a constructive effect in improving photosynthetic ability, nutrient uptake, growth, yield and economic benefits in legumes.

\section{REFERENCES}

1. Singh A, Carsky R, Lucas E, Dashiel K, et al. Soil n balance as affected by soybean maturity class in the 
guinea savanna of Nigeria. In; Lyasse O, Sanginga N, Vanlauwe B, Diels J, Merck R, (eds). Balance nutrient management systems for cropping systems in the tropics; from concept to practice. agriculture, ecosystem and environment, Special Issue 2003;100:231-40p.

2. Quaye W, Adofo K, Madode Y, Abdul-Razak A, et al. Exploratory and multidisciplinary survey of the cowpea network in the tolon kumbungu district of Ghana: a food sovereignty perspective. African Journal of Agriculture Research 2009;4:311-320.

3. Tarawali S, Singh B, Gupta S, Tabo R, Harris F, Nokoe S, Fernández-Rivera S, Bationo A, Manyong V, Makinde K, Odion E, et al. Cowpea as a key factor for a new approach to integrated crop-livestock systems research in the dry savannas of West Africa. In: Fatokun C, Tarawali S, Singh B, Kormawa P, Tamo M, (eds) Challenges and opportunities for enhancing sustainable cowpea production. International Institute of Tropical Agriculture, Ibadan, Nigeria 2002;233-251.

4. Eloward H, Hall, A. Influence of early and late nitrogen fertilization on yield and nitrogen fixation of cowpeas under well-watered and drier field conditions, Field Crop Research 1987;15:229-244.

5. Sanginga N, Dashiell K, Diels J, Vanlauwe B, Lyasse O, Carsky R, Tarawali S, Asafo-Adjei B, Menkir A, Schulz S, Singh B, Chikoye D, Keatinge D, Rodomiro $\mathrm{O}$, et al. Sustainable resource management coupled to resilient germplasm to provide new intensive cerealgrain legume-livestock systems in the dry savanna, Agricultural Ecosystem and Environment 2003;100:305-314.

6. Bressani R. Nutritive value of cowpea. in cowpea research, production and utilization (Singh S, Rachel K, (Eds)). Wiley and Sons Chester UK. 1985;3533360.

7. Timko M, Singh B. Cowpea, a multifunctional legume In: Genomics of tropical crop plants, Moore P, Ming R. (Eds), Springer science and business media, LLC, New York. 2008;227-258p.

8. Sanchez P, Salinas J. Low-Input technology for managing oxisol and ultisolsin tropical America. Advanced Agronomy Journal 1981;34:279-406p.

9. Carsky R, Iwuafor E. Contribution of soil fertility research maintenance to improve maize production and productivity in Sub-Saharan Africa, In: BaduAparaku B, Fakorade M, Ouederago M, Quin F. (eds), Strategies for sustainable maize production in West and Central Africa. Proceedings of a regional maize republic, 1999;3-20p.

10. Sanchez P, Walter C, Stanly W, et al. The fertility capability classification system: interpretation, applicability and modification. Geodermer 1979;27:283-309.

11. Fox R, Kang B. Sulphur requirements of cowpea and implications for production in the Tropics. American Society of Agronomy 1977;69:201-205.
12. Mokwunye A, Bationo A. Meeting the phosphorus needs of soils and crops of West Africa: The role of indigenous phosphate rocks. In: Vanlauwe B, Diels J, Sanginga N, Merckx R. (Eds). Integrated plant nutrition management in Sub Saharan Africa; from concept to practice, CABI/IITA, Cromwell Press, Trow Bridge. 2002;209-224p.

13. Haruna I, Aliyu L. Yield and economic returns of sesame (Sesamum indicum. 1.) as influenced by poultry manure, nitrogen and phosphorus at Samaru, Nigeria. Elixir Agriculture. 2011;39:4884-4887.

14. Ndakidemi P, Dakora F. Yield components of nodulated cowpea (Vigna unguiculata (L.) Walp) and maize (Zea mays) plants grown with exogenous phosphorus in different cropping systems. Australian Journal of Experimental Agriculture 2007;47:587-590.

15. Nkaa F, Nwokeocha O, Ihuoma O, et al. Effect of phosphorus fertilizer on growth and yield of cowpea (Vigna unguiculatalp. L Walp). Journal of Pharmacy and Biological Sciences 2014;9:74-82.

16. Nyoki D, Ndakidemi P. Effects of phosphorus and Bradyrhizobium japonicum on growth and chlorophyll content of cowpea (Vigna unguiculata (L) Walp) American Journal of Experimental Agriculture 2014;4:1120-1136.

17. Ndor E, Dauda N, Abimuku E, Azagaku D, Anzaku H, et al. Effect of phosphorus fertilizer and spacing on growth, nodulation count and yield of cowpea (Vigna unguiculata (L) Walp) in Southern Guinea savanna agro-ecological zone, Nigeria. Asian Journal of Agricultural Science 2012;4:254-257.

18. Okeleye K, Okelana M. Effect of phosphorus fertilizer on nodulation, growth and yield of cowpea (Vigna unguiculata l. walp) varieties. Indonesian Journal of Agricultural. Science 2000;67:10-12.

19. Singh A, Baoule H, Ahmed A, Dikko U, Aliyu M, Sokoto J, Alhassan M, Musa M, Haliru B, et al. Influence of phosphorus on the performance of cowpea (Vigna unguiculata (1) walp.) varieties in the Sudan savanna of Nigeria. Journal of Agricultural Science 2011;2:313-317.

20. Giller K, Amije F, Brodrick S, Edje O, et al. Environmental constraints to nodulation and nitrogen fixation of Phaseolus vulgaris l. in Tanzania ii. response to $\mathrm{N}$ and $\mathrm{P}$ fertilizers and inoculation with Rhizobium. African Crop Science Journal 1998;6:171-178.

21. Ssali S, Keya S. The effects of phosphorus and nitrogen fertilizer level on nodulation, growth and dinitrogen fixation of three bean cultivars. Tropical Agriculture 1986;63:105-109.

22. Ndakidemi P, Dakora F, Nkonya E, Ringo D, Mansoor $\mathrm{H}$, et al. Yield and economic benefits of common bean (Phaseolus vulgaris) and soybean (Glycine max 1.) inoculation in Northern Tanzania. Aust. J. Exp. Agric 2006;46:571-577.

23. Agboola A, Obigbesan G. Effect of different sources and levels of $\mathrm{P}$ on the performance and $\mathrm{P}$ uptake of Ife-brown variety of cowpea. Ghana Journal of Agricultural Science 2001;10:71-75. 